\title{
Study of Reproductive efficiency and Histological Changes in Liver and Kidney Associated With Sub acute and Acute Dose of Chlorpromazine (Largctil) in Mice Mus Musculus
}

\author{
Lec. Zaynab A. Shabab \\ Department of Physiology, Pharmacology and Chemistry, College of Veterinary medicine, \\ University of Basrah-Iraq
}

\begin{abstract}
The study was conducted on laboratory mice with body weight of 20-25 $\mathrm{g}$. The male mice was divided into three groups (A, B and C) each group contain three replicate and each replicate contain 5 animals. A and B group were treated orally with (1.8 and $3.6 \mathrm{mg} / \mathrm{kg} /$ day) respectively, while C group used as control and orally given $0.9 \%$ normal saline and determined the histological parameters during ( 21 days) and the second part of experiment was divided into 3 group from female mice each group consist of (6) female first the control treated with $(0.9 \% \mathrm{Nacl})$ while the (second, third group) treated with chlorpromazine $(1.8$ and $3.6 \mathrm{mg} / \mathrm{kg} / \mathrm{day}$ for 14 days before matting and then all females they were gathered to mate with normal male for sixteen days.

The histological study showed In both doses of Chlorpromazine of liver and kidney was represent by necrosis, vacuolization, hemorrhage, and complete cell membrane degeneration in hepatocytes and kidney cells, as well as recorded the lymphocytes infiltration in treated group, While the control not showed any histopathological changes during the study. The results of second experiment show all females of experiment except the third group which treated with (3.6 )mg from chlorpromazine not conceive and delivered but the control group and second group was conceive.
\end{abstract}

Kay Word: Chlorpromazine, Histopathological, Liver, Kidney, mice

\section{Introduction:-}

Chlorpromazine is an antipsychotic drug was once of the most commonly antipsychotic agent. This drug can be cause mild with transient elevations in serum enzyme as well as a well-known cause of clinically apparent acute with chronic cholestatic liver (Orellana et al., 2006). This field which show large growth in recent years, due to differentiation the drug-stimulate liver disease with effects in reproductive system, the most common cause to liver defects and a major contributors to the drawal of drugs developed. Drug-prompt Liver disorder, 3rd edition is a overall reference that covers mechanisms of the injury, diagnosis with management, major hepatotoxin (Kunimatsu et al., 2001).). Antipsychotic drugs are central nervous system -influencing drugs that are used in most psychiatric hospital to treat people with mental disorders (Hollister;1995). The drug have been reported to have the ability to permeate the biomembrane barriers of most reproductive organs(Baldessarini; 1980). The 


\section{University of Thi-Qar Journal of agricultural research}

ISSN Onlin:2708-9347, ISSN Print: 2708-9339 Volume 9, Issue 1 (2020) PP 99-107

compound (chlorpromazine) affected on dopaminergic receptors and used to treat schizophrenia.(Bargiota $e t$ $a l$;2013). Hyperprolactinemia induced by this drugs in men are impotence, cause it lead to loss of libido and hypospermatogenesis (Petty;1999). Mechanism action of this drug on reproduction is by blocking dopamine receptors and also by increasing the conversion of androgens to estrogens thereby elevating the plasma levels of the latter hormone these effects lead to alteration in male reproductive efficiency sufficient to cause male infertility(Raji etal;2005).

Hence the present study was conduced to evaluated the effects of Chlorpromazine as (Antipsychotic drug) on some reproductive efficiency in female mice and histological changes which occurs in liver and kidney .

\section{Materials and Methods:-}

Drugs: Commercially available Largctil tablet (Chlorpromazine). Each contains 100mg chlorpromazine hydrochloride. manufactured by ADWIA Co. S.A.E., 10th of Ramadan City, Egypt).

Fifteen male and 18 female mice used in the study weighting between $20-25 \mathrm{~g}$. They were housed in clean cages and fed with clean water and food. After that, animals (males) divided into three groups; Control group. which include 5 mice administrated orally with normal saline only, low dose group consists of 5 mice were recevied to $1.8 \mathrm{mg} / \mathrm{Kg}$ drug administrated with distill water and the high dose group consists of 5 mice were exposed to $3.6 \mathrm{mg} / \mathrm{kg}$ drug administrated with distill water. All these groups administrated once daily for 3 weeks. They were administrated at the same time in the morning (10-11) Am administration. After the duration of administration, all groups will inject with ketamine $0.5+x y l a z i n$ (to avoid suffering during killing). Kidney and liver were taken out after killing for histological study. While the second part of experiment was divided into three group each group included 6 female mice the first group treated with( Nacl 0.9\%) for 14 days before matting. Whereas the second and third group treated with chlorpromazine (1.8 and $3.6 \mathrm{mg} \backslash \mathrm{kg}$ ) for 14 days daily before matting, after treated all females they were gathered to mate normal males for sixteen days

\section{Histopathological study:}

The microscopically analyses was made through the observation the changes in morphological tissues of liver and kidneys of the mice were removed and fixed in ( $10 \%$ ) neutral buffered formaldehyde for $72 \mathrm{~h}$, Specimens were process by dehydrating and clearing was performed by alcohol and xylene respectively. Tissue specimens were impregnated and embedded in paraffin and stained by hematoxylin and eosin stain (Luna, 1968). 


\section{Results:-}

\section{Histopathological result:}

1- Liver

sections of liver of the control group showed normal size with shape, normal structure of central vein. and hepatocytes Fig1. The characteristic features of liver damage in mice in group (Largctil = 1.8 $\mathbf{~ m g} / \mathbf{k g} / \mathbf{~ d a y}) \mathrm{was}$ revealed by histopathological changes in liver represented congestion, bleeding and vaculation of hepatocytes. Fig.2, While, group $($ Largetil = $\mathbf{3 . 6} \mathbf{~ m g} / \mathbf{k g} /$ day $)$ appeared Sinusoidal dilatation, degeneration and analysis nuclei Fig.3 , also Showed Congestion, bleeding, necrosis, acute infiltration of macrophage and degeneration Fig.4.
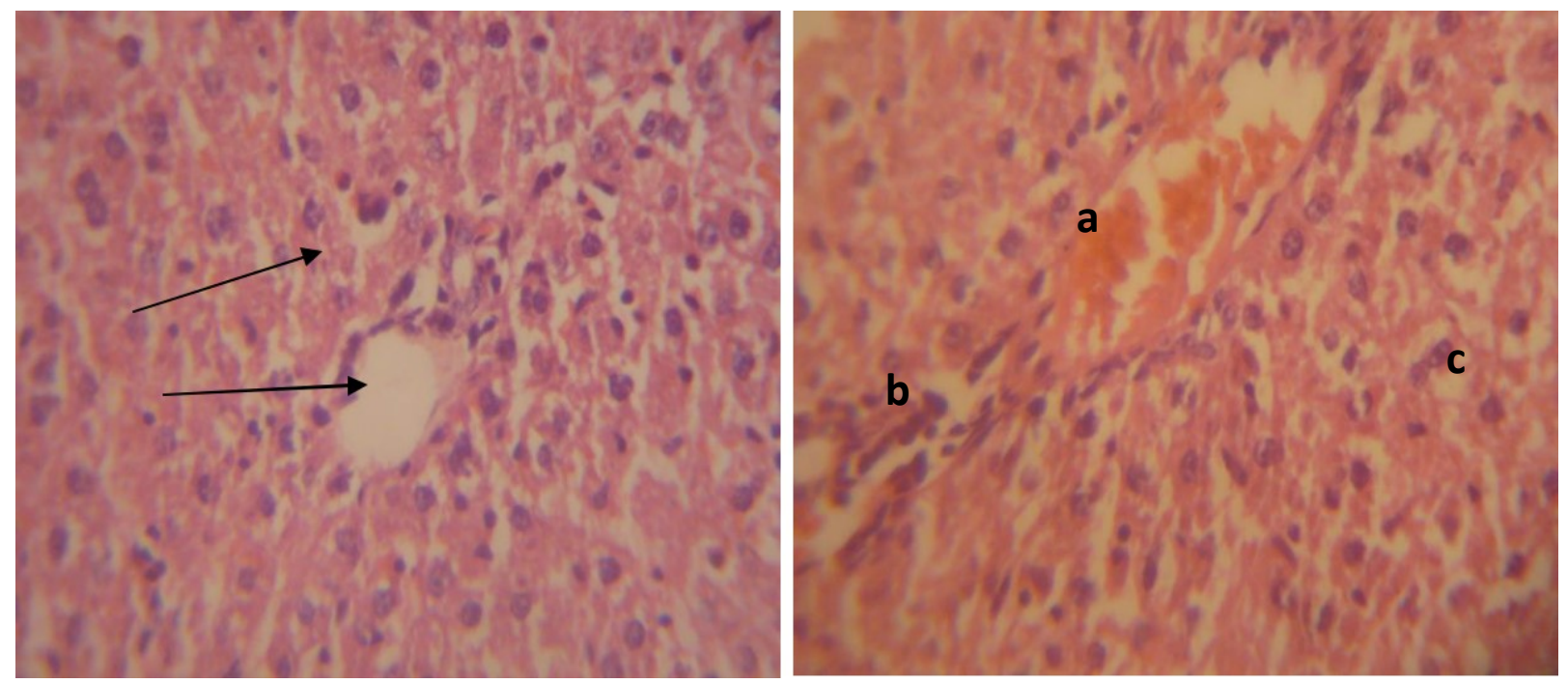

Fig1. Liver of control G. showed the normal size with shape of liver structure , during normal structure C.V. and hepatocytes(arrow).( 40X E and H)
Fig2. Liver, Showed changes in liver structure represented by congestion(a), lymphocytes infiltration(b) and vaculation of hepatocytes(c)

(1.8 mg/kg/day). (40X E and H) 


\section{University of Thi-Qar Journal of agricultural research}

ISSN Onlin:2708-9347, ISSN Print: 2708-9339 Volume 9, Issue 1 (2020) PP 99-107

https://jam.utq.edu.iq/index.php/main $\quad$ https://doi.org/10.54174/UTJagr.Vo10.N1/11

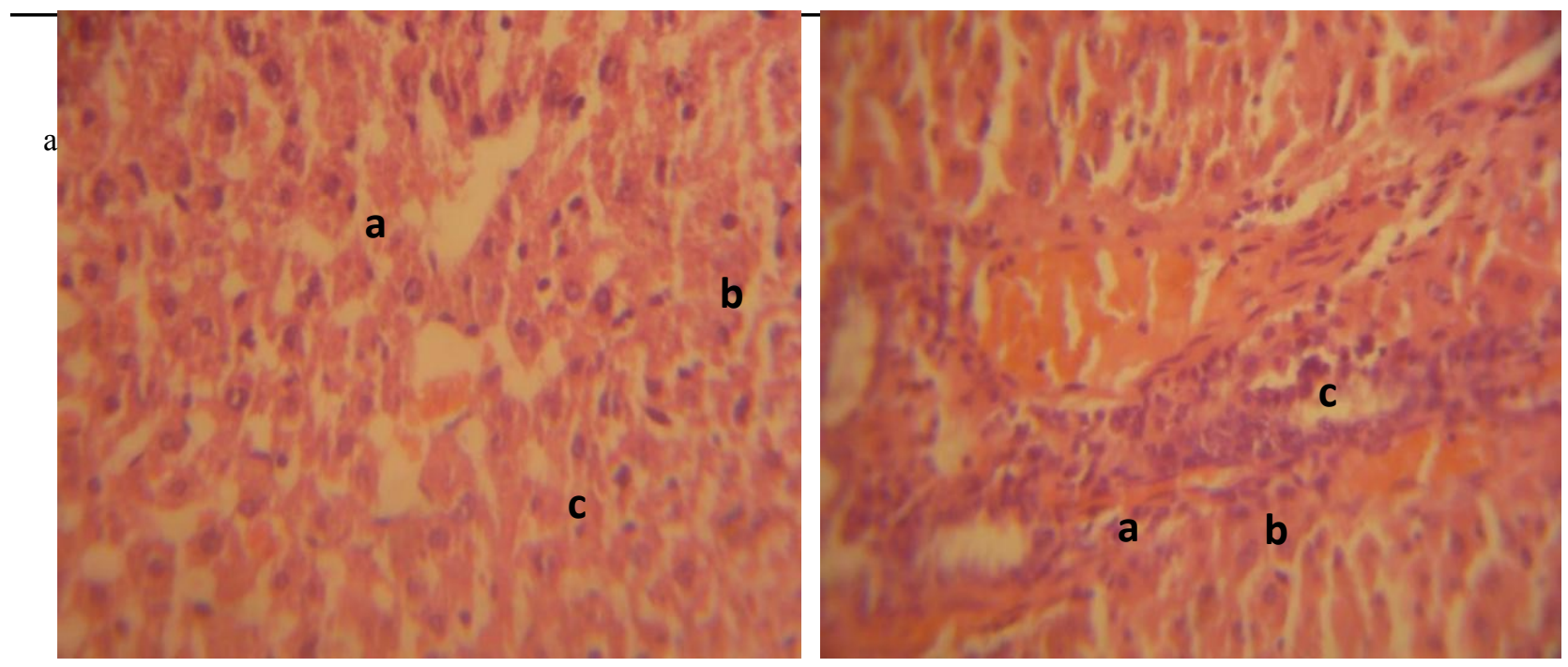

Fig.3. Liver, Appeared Sinusoidal dilatation(a), degeneration(b) and analysis nuclei(c),

$3.6 \mathrm{mg} / \mathrm{kg} / \mathrm{day})$. (40X E and H).
Fig.4. Liver, Showed Congestion(a), bleeding, (necrosis, acute infiltration of macrophage c) and(b) degeneration (3.6 mg/kg/day). (40X E and H).

\section{2- Kidney}

Histologically ,the control kidney tissue indicated the presence of normal cuboidal shaped cell with defined epithelial cell lining Fig 5. In the treatment group with( 1.8)mg was showed that shrinkage of glomeruolosa and necrosis of tubules Fig.6. also showed state of vaculation, degeneration and necrosis Fig. 7,. Also showed infiltration of lymphocytes, absent of glomerulus Fig.8.
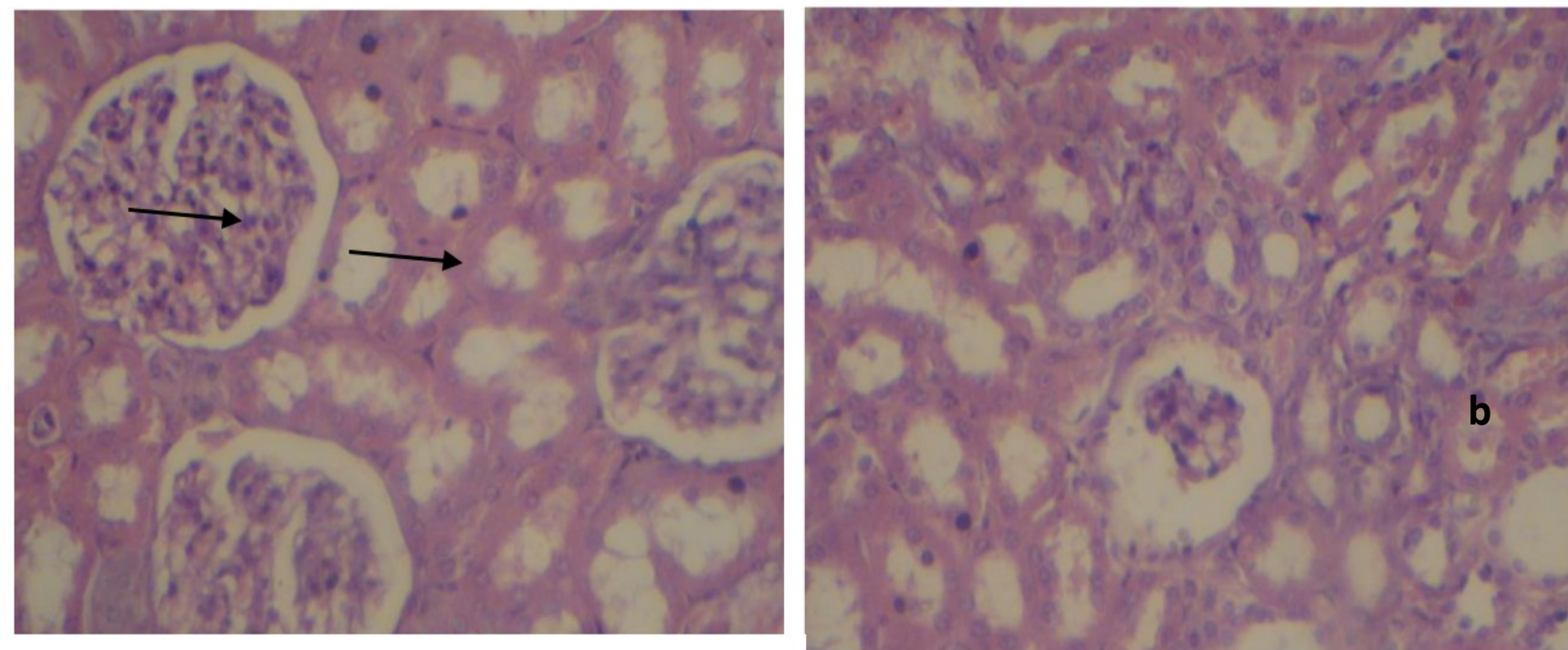
ISSN Onlin:2708-9347, ISSN Print: 2708-9339 Volume 9, Issue 1 (2020) PP 99-107 https://jam.utq.edu.iq/index.php/main $\quad$ https://doi.org/10.54174/UTJagr.Vo10.N1/11

Fig. 5. Control kidney tissue indicated the presence of normal tubular epithelium and shaped cell ( arrow). 40X E and H
F ig.6. Showed that shrinkage of glomerulus(a) and necrosis(b) of tubules( $1.8 \mathrm{mg} / \mathrm{kg} /$ day). ( 40X) glomurulas 


\section{University of Thi-Qar Journal of agricultural research}

ISSN Onlin:2708-9347, ISSN Print: 2708-9339 Volume 9, Issue 1 (2020) PP 99-107 https://jam.utq.edu.iq/index.php/main $\quad$ https://doi.org/10.54174/UTJagr.Vo10.N1/11
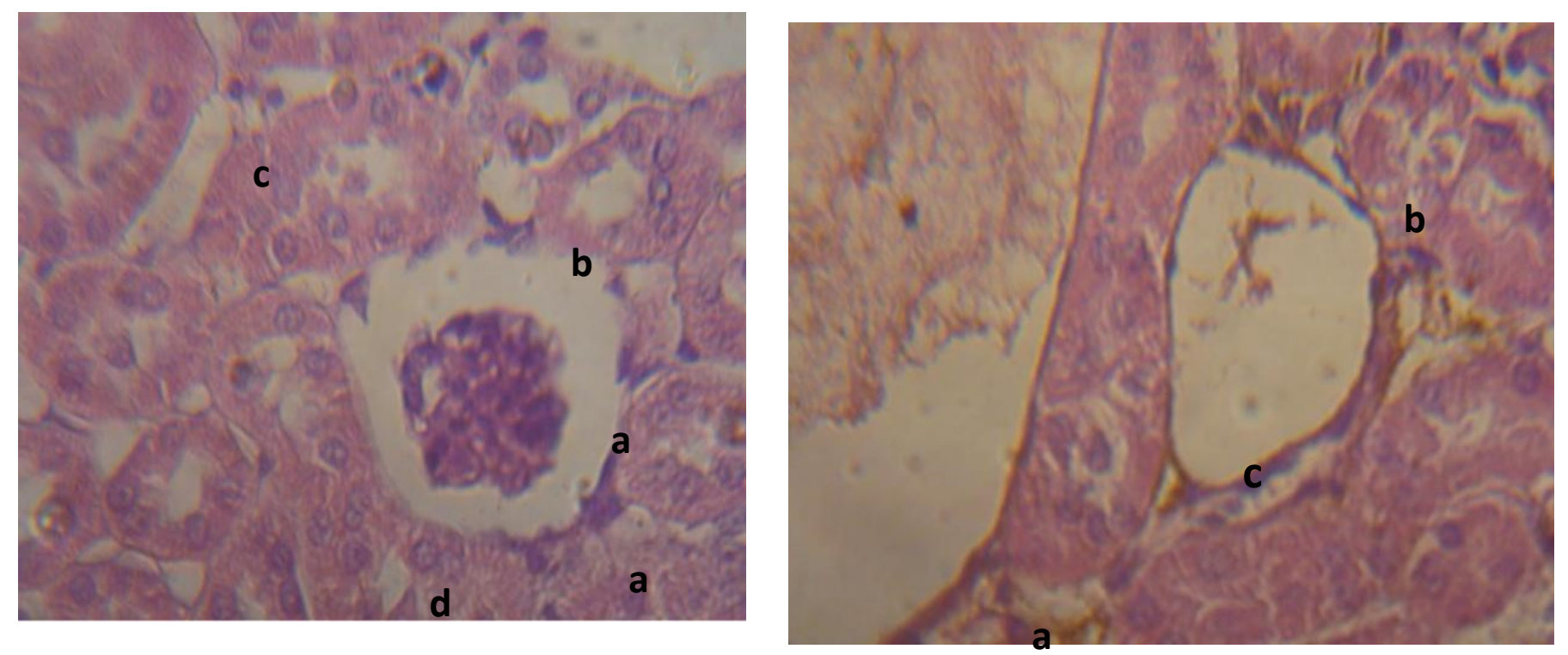

Fig.8. Showed vaculation(a), degeneration(b) and

Fig.7. Showed vaculation(a), degeneration(b) and absent of glomerulus(c)( $3.6 \mathrm{mg} / \mathrm{kg} / \mathrm{day})$. (40X E necrosis (c) and in some tubules and glomerular(d) (3.6 $\mathrm{mg} / \mathrm{kg} / \mathrm{day})$. (40X E and H). 


\section{2-Reproductive efficiency results:}

All females of this experiment except the third group treated with $3.6 \mathrm{mg} \backslash \mathrm{kg}$ of chlorpromazine not pregnant , while the control group; and second group was treated with $1.8 \mathrm{mg} \backslash \mathrm{kg}$ from chlorpromazine was conceive but in the second group the number of females was conceive only four, as compared with control group (8) female . The number of offspring in the control group was 35 while in the second treated group was( 11) only and the number of male in the control group was 21 Male and 14 females as compared with second treated group was 6 male and 5 females. Table(1): The effect of chlorpromazine on fertility aspects in females mice.

\begin{tabular}{|c|c|c|c|c|}
\hline $\begin{array}{c}\text { No of females } \\
\text { Group }\end{array}$ & $\begin{array}{c}\text { No. of pregnant } \\
\text { females }\end{array}$ & No. of litters & No .of Males & No. of females \\
\hline $\begin{array}{c}\text { Control G } \\
6 \text { Female }\end{array}$ & 6 & 35 & 21 & 14 \\
\hline $\begin{array}{l}\text { Second G } \\
6 \text { Female }\end{array}$ & 4 & 11 & 6 & 5 \\
\hline $\begin{array}{l}\text { Third G } \\
6 \text { Female }\end{array}$ & 0 & 0 & 0 & 0 \\
\hline
\end{tabular}

\section{Discussion:-}

Through the study of the effects of Chlorpromazine ( Largctil) on both liver and kidney was dose depended. There's increasing effects with doses level administration. Drug levels in the blood stream affected through capillary contraction this lead to decline in filtration of drug by glomerular. Liver test disorders have been reported to occur in up to $41 \%$ case with long term therapy of drug. The enzymes (AST,ALT ) abnormalities which usually self-limited and unaccompanied by symptoms (Zelman, 1959). Chlorpromazine , is a once of most commonly antipsychotic drug. Chlorpromazine can lead to mild and transient serum enzyme changes, also cause clinically apparent acute with chronic cholestatic liver injury (Wieck., 2003). several cases of clinically apparent acute and sever liver defect due to treated with this drug have been reported in the literatures, occurs in 1:500 persons exposed. Chlorpromazine was the most cause to induced liver defect in United States, with decrease in its use, chlorpromazine related with signs of jaundice disease is now rarely reported (Smith, 2003). The onset of this disease( jaundice) which is usually begins within 1 to 5 weeks and serum enzyme changes typically to cholestatic or mixed (Smith, et al., 2002). The mechanism of chlorpromazine drug which causes serum elevations is not known. The clinically apparent of liver injury due to the drug is likely due to hypersensitivity, based upon the clinical features of a short latency period, eosinophilia, fever with rapid recurrence upon re exposure. The drug which metabolized by the liver through oxidation, some cases of serum 
aminotransferase changes as well as more clinically apparent liver injury may be caused by production a toxic intermediate of metabolism. (Rehm, et al., 2007). Nephroprotective drugs reduce renal ischemia and chlorpromazine, leave this clinical potential. This benefit can be caused by generalized vasodilation with improved blood flow through chlorpromazine (Chien et. al., 1977). However the drug has anesthetic and sympatholytic properties which lead to decrease of calcium influx, inactivation of phospholipase and inhibition of $\left(\mathrm{Na}^{+} / \mathrm{K}^{+}\right.$-ATPase), determine the increase renal blood flow and restoring urine flow. These actions because improved cell function (Jayachandran, et. al., 1985). In this study also can be seen the effect of chlorpromazine in reproductive efficiency was no pregnant all females which treated with large dose (3.6)mg and decline the pregnant females treated with low dose (1.8)mg from chlorpromazine to four only as compared with control group because all this medication are associated with increased effect of sexual dysfunction(Okeane;2008). Researchers have shown the effects of chlorpromazine drug on fertility, sexual efficiency and bone mineral density (Bostwick etal ;2009). In another study treated female rats with three doses(3, $10,30 \mathrm{mg} \mathrm{kg}$ per day for 28 days which lead to significantly differences between

the treated animals and the control group on the size of the normal corpora lutea and increased dysfunction of the ovaries dependent on the concentration of drug, the serum level of prolactin and progesterone hormones increase, while the levels of ( estradiol, LH and FSH) decline depending on the dose of drug, chlorpromazine induced unsuccessful matting of animals with decreased pregnancy rate(Zahra etal;2015).The results of this study have demonstrated decreased potential fertility at large doses of chlorpromazine drug.

\section{Reference:-}

1. Baldessarini , $\mathbf{R}$.j.(1980). Drugs and the treatment of Psychiatric disorders: depression and anxiety disorders .In: Goodman and Gilmans pharmacological Basis of therapeutics (Ed). MacMillan Pub .Co. Inc. New York, pp:301-417.

2. Bargiota, S.; Bonotis, K.; Messinis.;I and Angelopoulos.;N.(2013). The effects of antipsychotics on prolactin levels and women's menstruation. Schizophr Res. Nov;1-10.

3. Bostwick, J.R; Guthrie. S.K.and Ellingrod. V.L.(2009). Antipsychotic- induced hyperprolactinemia. Pharmacotherapy. 29(1): 64-73.

4. Chien, K.R; Abrams. J; Pfau. R.G. and Farber. J.L.(1977). Prevention by chlorpromazine of ischemic liver cell death. Am J Pathol. 88: 539-54.

5. Hollister, L.E.(1995). Antipsychotic and lithium in basic and clinical pharmacology by katzung, B.G. $\left(6^{\text {th }} E \mathrm{~d} n\right), \mathrm{pp}: 433-447$.

6. Jayachandran, S; Mooppan. M.M; Chou. S.Y. and Kim. H. (1985). Effects of chlorpromazine on ischemic rat kidney: a functional and ultrastructural study. Urology. Abr. 25(4):386-90.

7. Kunimatsu, T; Kimura. J; Funabashi. H; Inoue. T.and Seki. T. (2001). The antipsychotics haloperidol and chlorpromazine increase bone metabolism and induce osteopenia in female rats. Regul Toxicol Pharmacol. 58(3): 360-368

8. Luna; L. C. (1968). Manual of histological staining methods of the armed forces institute of pathology McGRAW-HILL Book Company USA 
9. Okeane,V.(2008). Antipsychoitic- induced hyperprolactinemia,hypogonadism and osteoporosis in the treatment of schizophrenia .J Psychopharmacol .Vol.(22).(2):70-75.

10. Orellana, J.A; Palacios-Prado ;N. and Saez. J.C.(2006). Chlorpromazine reduces the intercellular communication via gap junc - tions in mammalian cells. Toxicol Appl Pharmacol. 213(3): 187-197.

11. Petty, R.G.(1999). Prolactin and antipsychotic medications: Mechanism of action. Schizophrenia. Res; 35:S67-S73.

12. Raji, Y.; Ifabunmi, S.O; Akinsomisoye, O.S; Morakinyo, A.O. and Oloyo, A.K. (2005). Gonadal responses to antipsychotic drugs: chlorpromazine and thioridazine reversibly suppress testicular functions in albino rats. International Journal of pharmacology 1, (3):287-292.

13. Rehm, S; Stanislaus. DJ .and Wier. PJ.(2007). Identification of drug-in - duced hyper or hypoprolactinemia in the female rat based on general and reproductive toxicity study parameters. Birth Defects Res B Dev Reprod Toxicol. 80(3): 253-257.

14. Smith, S; Wheeler. M.J.; Murray. R. O. and Keane. V.(2002). The effects of antipsychotic-induced hyperprolactinaemia on the hypothalamicpituitary-gonadal axis. J Clin Psychopharmacol. 22:109-14.

15. Smith., S. (2003). Effect of antipsychotics on sexual and endocrine functions in women. Implication for clinical practice. J Clin Psychopharmacol.23:S27-S32.

16. Wieck., A.(2003). Haddad PM. Antipsychotic-induced hyperprolactinaemia in women: pathophysiology, severity and consequences. Selective literature review. Br J Psychiatry.;182;199204.

17. Jwar, A. S., \& Abdul-Wahid, M. S. (2018). Effect of different pollen grain source and chitosan on some physiological and enzymatic characteristics of data palm Phoenix dactylifera L. fruits cv. Alshwethey. Basrah Journal For Date Palm Research, 17(1-2).

18. Zahra, Z; Samad .Z ;Rajabali .S ;Abbas .A .and Elham .M.(2015). The effects of chlorpromazine on reproductive system and function in female rats .Int J of Fertility and Sterility.; Vol.9(3):371-379.

19. Zelman., S.(1959). Liver cell necrosis in chlorpromazine jaundice allergic cholangitis a serial study of 26 needle biopsy specimens in nine patients. Am J Med 27: 708-29. 